\title{
Controlling Methods for SMEs' Risk Reduction
}

\author{
LAKATOS Vilmos ${ }^{1}$ - IPOLYI Vanda Vivien ${ }^{2}$ - TÍMÁR Tímea ${ }^{2}$ \\ ${ }^{1}$ Department of Economics, Finance, and Management, Faculty of Economics, \\ John von Neumann University, Hungary \\ ${ }^{2} 3$ rd grade Students of Finance and Accounting BSc, Faculty of Economics, \\ John von Neumann University, Hungary
}

\begin{abstract}
Keywords:
SMEs, risk factors, controlling methods, cost calculation, the evaluation of suppliers and customers
\end{abstract}

\begin{abstract}
A substantial proportion of entrepreneurs strive to reduce the risk of their activity, which means they refer to a number of methods known, but rarely applied by them. Risk reduction activities can be totally interconnected with the 'controlling' approach and methods that are still not well known to a lot of company executives, but the introduction and application of those methods provide tangible results for business decision-makers within a relatively short period of time. The paper presents the size, activity, financial process characteristics, planning features, suppliers and buyers' evaluation practices of the investigated SMEs using correlation analysis methods. The study is a continuation of a research topic that has been going on for many years and is based on data collection from the years 2015 and 2016. We have evaluated the planning and management features of a total of 53 micro, small and medium-sized enterprises by questionnaire processing.
\end{abstract}

\section{Összefoglalás}

$\mathrm{Az}$ utóbbi időszak gazdasági kutatásai, illetve a vállalkozások gazdasági tevékenységeinek elemzése során a közgazdászok arra figyeltek fel, hogy a kkv szektoron belül - mintegy 10\%-os arányban - dinamikusan fejlődő vállalkozások jelentek meg. Ezek a vállalkozások arra képesek, hogy a növekedési ütemük 3-5 éves időszak alatt meghaladja akár az évi 20\%-ot is. Ezeket a vállalkozásokat a szakirodalom gazella típusú vállalkozásoknak nevezi. A jövőben fontos kérdés a gazella típusú vállalkozások részarányának növelése a kkv szektoron belül, mivel így a kkv-ék, a gazellák, illetve a kkv szektor a tartós és fenntartható növekedési pályára állhat.

A gazellává válást magyarázó tényezők elemzése lényeges gazdaságpolitikai szempontból, hiszen ez alapján azonosítható a potenciális gazellák csoportja. A gyors növekedést magyarázó tényezők elemzése segít annak megértésében is, hogy milyen tényezők akadályozzák más vállalatok gyors növekedését. [2] [3]

A vállalkozások méretüktől és tevékenységi körüktől függetlenül a folyamatos kockázatvállalással jellemezhetők, ugyanis már maga a tevékenység általános megnevezése vállalkozás jelzi, hogy tudatosan vállalnak olyan folyamatokat, amelyek a jövőbeni kifutásukat illetően bizonytalansággal, ezáltal kockázattal járnak. A menedzsment számára nem lehetséges, hogy számításba vegye a kockázatok valamennyi forrását, de több megoldás is rendelkezésre áll, hogy felkészítse a vállalatot az esetleg bekövetkező kockázati kihívás megválaszolására [4].

Kadocsa és munkatársai [5] több menedzsmenti módszert vizsgáltak, amelyek a vállalkozások, kifejezetten a kkv-k fejlesztési lehetőségeire irányultak. Ezek közül a kontrolling a vizsgált vállalkozások mindösszesen 20 \%-ánál történt meg - ez azonban nem jelenti önálló kontroller, vagy kontrolling szervezet létrehozását ilyen arányban -viszont un. kontrolling funkciók, mint pl. a tervezés már nagyobb arányban került alkalmazásra: dokumentált stratégiai terve 37\%-nak, üzleti terve $46 \%$-nak volt. Megállapításuk szerint a hazai kkv szektor versenyképességének sarkalatos pontja a költséghatékonyság és a termelékenység. A költséghatékonyság fejlesztésében a kontrolling rendszer már világszerte 
bizonyított, a nagyvállalati körben széleskörúen elterjedt és a vezetés hasznos, nélkülözhetetlen eszközévé vált.

Az előzőekben ismertetett tényeket 2016 őszén és 2017 tavaszán 53 vállalkozásból nyert saját vizsgálatokkal kíséreltük meg tovább elemezni.

A kérdőíves felmérés érintette a vállalkozás méretét, a tevékenységhez a menedzsmenthez való hozzáértés meglétét, a vagyoni struktúra jellemzőit, a beszállítói és vevői kapcsolatok minőségét, a likviditás helyzet értékelését, egy kérdéscsoport foglalkozott a vállalkozások kontrolling jellemzőivel: tervezési-elemzési, irányítási és információs folyamataival, majd a költségkalkulációkkal és költségallokációkkal, mely a mikro-kis- és középvállalkozások (mkkv-k) menedzsmenti tevékenységének továbbra is egyik gyenge láncszemének tekinthető. Újabb vizsgálati elemet jelent a kockázatkezelés szempontjából különösen fontos vevői-szállítói kapcsolatok elemzése, amely részben a vállalkozás menedzsmentjétől független tényezőként is kezelhető (vevő fizetőképessége-készsége vagy a szállító korrektsége a határidők és teljesítések tekintetében).

A sikeres tevékenységhez nélkülözhetetlen mind a szakmai hozzáértés, mind az üzletviteli-gazdálkodási ismeretek megléte. A vállalkozások 90 \%-ánál a szakmai ismeretek dokumentáltan adottak voltak, a vezetők vagy már a vállalkozás indításakor eleve rendelkeztek szakirányú végzettséggel, vagy a kezdeti múködés során szereztek végzettséget tanúsító bizonyítványt. A szakmai hozzáértést mutatja az a tény is, hogy a menedzserek 57\% a felsőfokú végzettséggel rendelkezik.

A vállalkozások megítélése alapján komoly kockázati tényező a szállító-vevő kapcsolatok milyensége. Természetes, hogy a vállalkozások több éve a megbízhatóságra törekedve alakítottak ki egy stabil múködést támogató beszállítói és vevői környezetet, de a fejlesztési elvárások a növekedés irányába, ezáltal a korábbi partnerek bővítésére ösztönöznek. Az új kapcsolatok magukban hordják a kockázatokat, de ezeket vállalják a vezetők és egy részük kezelhető szinten kívánja tartani a vevőket és szállítókat minősítő eljárások alkalmazásával. A kérdőíves felmérésben a szállítók és vevők versenyeztetésének teljes körü vizsgálata még nem volt lehetséges, ugyanis az egyéni vállalkozások többsége még ezt nem alkalmazza, e a gazdasági társaságok üzletviteli ismeretekkel rendelkező vezetése már tudatosan választja ki és változtatja is a szállítóit és rangsorolja a vevőit az árbevételhez és fedezethez történő hozzájárulás alapján.

Összességében megállapítható, hogy a vállalkozások méretüktől függetlenül tudják kezelni a kockázati tényezők hatásait menedzsmenti tevékenységükön keresztül, s ez annál sikeresebb, minél tudatosabban használják a rendelkezésre álló eszközöket, mint a tervezést, terv-tény elemzést, vállalati partnerek minősítését, kommunikációt, stb., amelyek mind szoros kapcsolatban vannak a kontrollinggal. Ez a tevékenység különösen a mikro-kis- és középvállalkozásokban ütközik akadályba, ahol a nem közvetlen értékteremtés sokszor háttérbe szorul, nem számolva azok hosszú távú előnyeivel.

\section{Introduction}

This study is the continuation of a research (based on data collection) carried out between 2015 and 2016. We managed to analyse the planning- and enterprise leading characteristics of 53 SMEs altogether with the use of survey processing. A high percentage of entrepreneurs make an effort to reduce risks. To reach this aim, they mention several methods known but rarely applied by them. The risk-reducing activities can be fully connected with the so-called controlling approach and methods. With the introduction and application of the methods mentioned above, the palpable results for the decision-makers of the enterprises arrive in a relatively brief time. This study will demonstrate the characteristics of the size, scope of activity, financial procedure, planning, supplier and customer evaluation of the analysed SMEs. 


\section{The role of SMEs in the national economy}

The analysis of the Central Statistical Office (CSO) from November 2016 [1] compare the characteristics of SMEs, according to their regional division for a period of 3 years. In this study, the main aim of the CSO was to define the so-called 'real SMEs', which means they did not necessarily categorize the enterprises according to Eurostat criteria, but tried to form a definition which refers only to small, independent organisations (e.g. besides headcount, revenue and balance sheet size, the rate of state/foreign ownership is also considered).

One characteristic of active SMEs is territorial concentration. The importance of central Hungary is outstanding, 4 out of 10 organisations can be found here, the share of other regions was between $8.0-11.4 \%$ from 2013 to 2015 . ( $1^{\text {st }}$ figure)

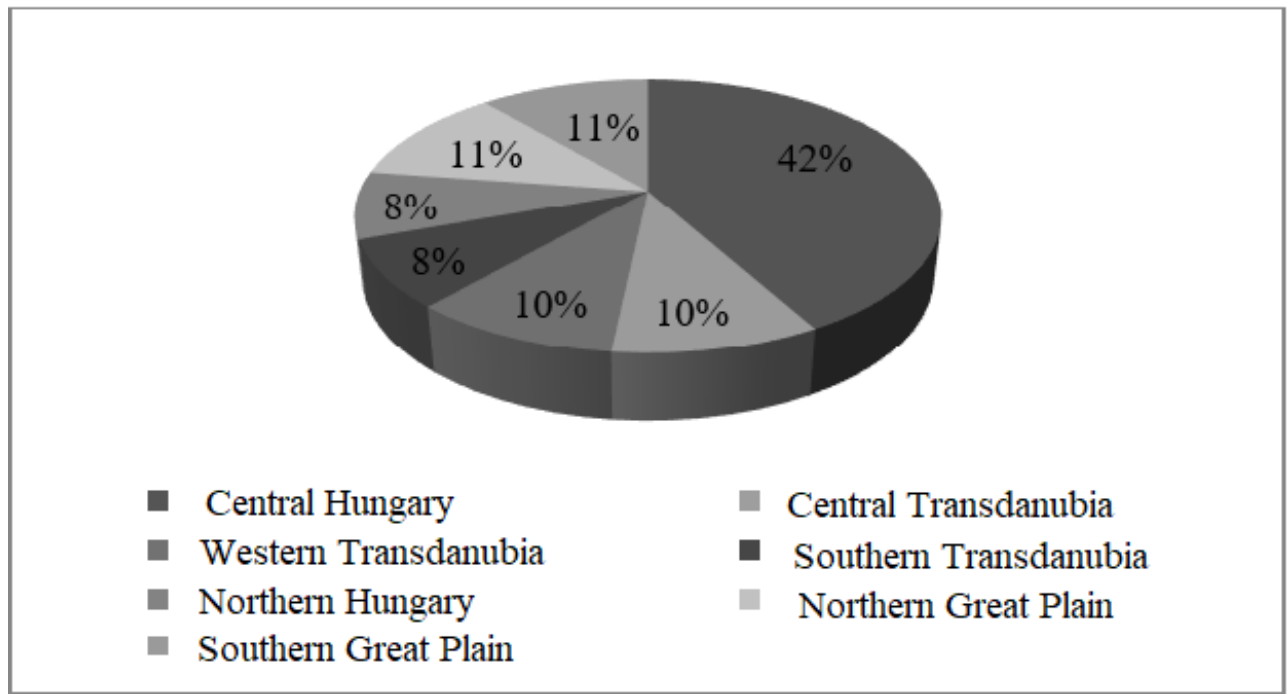

Figure 1: Share of the number of SMEs according to regions [1]

In $201362.9 \%$ of active SMEs were joint businesses, $37.1 \%$ were individual holdings, while in 2014 the rate of joint and non-profit businesses together was $60.9 \%$ and the individual ones' $39.1 \%$. In 2015 the ratio of individual enterprises grew further (43.6\%), while that of joint businesses lowered (56.3\%); the ratio of non-profit businesses was $0.1 \%$. In 2013, 2014 and 2015 the ratio of individual businesses surpassed the national average in every region except for Central Hungary (including Budapest). In Central Hungary - because of the concentration of the capital - the ratio of joint businesses was outstanding: in 2013 and 2014 it exceeded $75 \%$ and in 2015 it was nearly $70 \%$, whereas in the other regions the ratio of individual businesses and joint businesses was more balanced.

According to sector characteristics in every sector - except for agriculture - the Central Hungarian organisations are the majority, their dominance is mainly in the field of services, primarily in information, communication, real estate transaction and professional, scientific, technological activities, or rather in art, entertainment and leisure time. The ratio of agricultural businesses transcended 20\% in the Northern Great Plain in every examined year, and almost reached this percentage in the Southern Great Plain.

In 2013 in the case of revenues, the SMEs altogether realized an income of 34.0 thousand billion forints in Hungary, in 2014 this number was 36.3 thousand billion, in 2015 37.9 thousand billion. Despite the growing revenues between 2013 and 2015, the SMEs' share of the reached value of the whole enterprise sector reduced from $43.2 \%$ to $42.4 \%$. Although the organisations are mainly made up of SMEs, their share of the revenues differed considerably on a regional basis. In Southern Transdanubia and in the other two lowland regions, in every examined year the revenue of SMEs was between $52.3 \%$ and $60 \%$ relative to the revenue of the whole enterprise circle. The same ratio, in the case of Central Transdanubia, was only $33.8-35.3 \%$. 
In recent economic researches and throughout the analysis of different enterprises' economic activities, economists realized that within the SME sector - approximately in 10\% ratio - dynamically developing enterprises appeared. Within a period of 3 to 5 years, the development rate of these enterprises can exceed $20 \%$ annually. These enterprises are called gazelle type of enterprises by the academic literature. In the future, the question of increasing the ratio of these gazelle type enterprises within the SME sector will become more and more important, since with this move the SMEs, the gazelles, and the whole SME sector would be set on a stable and sustainable growth path.

The analysis of the explanation of quick growth is essential in terms of economic policy because it is the only way to identify the group of potential gazelles. The analysis of the explanation of fast growth also helps to understand what factors hold back the other enterprises from accelerated growth. [2] [3]

\section{Risk management methods}

The enterprise - regardless of its size and activities - can be described by continuous risk-taking, even the name of this activity - enterprise - indicates that they undertake different procedures, which can be unstable and therefore involve a variety of risks.

In the management's interpretation risk is a subjective definition. Lots of managers think that an enterprise or organisation just transmits the risk. As for the definition of risk, there is no widely accepted definition, but for its interpretation, we can find several examples.

- Risk arises from the difference between the expected and forthcoming reality. In other words, risk resides in the uncertainty of the return on the invested money, whether the amount has increased or decreased at the endpoint of the investment.

- Any event's probability of occurrence, which can affect the fulfilment of the enterprise's strategic target.

- An event, which impacts the organisation in reaching their potential aim, whether the event actually occurs or not.

- In case of normal distribution, the expected yield equals the average of past yields, while the risk equals the value of the standard deviation.

- The risk for market participants lies in the fact that from the moment of making their business decision till its fulfilment, the market conditions can shift contrary to their interest or they might not shift at all.

Wolfram Steiner [in 4] groups the different risk-types in the following way:

- outer impacts: e.g. the changes in the market, the competition, government or EU intervention, currency rate changes

- strategic and business risks: e.g. in connection with the knowledge of fellow competitors and the market, and with the protection of the brand name

- operational risks: e.g. computerized systems, imposture, the standard of customer service, training and motivating co-workers

- financial risks: e.g. the treasury, foreign exchange handling, financial reports

- in connection with the observation of laws, legislative provisions

For the management, it is not possible to take every source of risk into account, but three solutions are available to prepare the enterprise to answer the upcoming challenges [4]:

- They can enumerate the kind of risks the enterprise faced in the past and they can determine to what extent these risks are going to be a threat again. This kind of research is called Past Adapting Research.

- The enterprise can prognosticate where tensions might arise in the organisation, operation, control of the business and in the characteristics of the competition and background environments, which can cause risks later. The Trend-Strain Analysis tries to discover not only the inner and outer environment's tensions but to find problems between these two.

- Finally, the management can prepare for the risks coming from various sources, by taking the possible answers into account. Namely, they examine the scope provided 
by the possible answers in case of those business factors which can be formed by the enterprise itself through decision-making.

Kadocsa and his co-workers [5] examined several management methods, specifically constructed for the development of SMEs. Of these methods, controlling appeared at only $20 \%$ of the surveyed enterprises - but this does not mean the maintenance of an independent controller or controlling organisation at the same rate- on the other hand, controlling functions (e.g. planning) were applied at a higher rate: $37 \%$ of them had a documented strategic plan, $46 \%$ had a business plan. According to the conclusions of Kadocsa and his team, the inland SME sector's pivotal points are expense-efficiency and productivity. In the case of developing cost-efficiency, the controlling system proved its positive effects all around the world, among large companies controlling systems became widespread, useful and indispensable for the directory.

Referring to the facts mentioned above, the application of controlling as a management tool is still not a general tool of SMEs, although it has an accentuated role in decreasing the risks of any activity. Further on, the study is displaying the results of the examined enterprise circle and comparing those results with the information provided by academic literature.

\section{The use of risk-reducing controlling tools in the studied enterprises}

We tried to further examine the facts presented above in 2016 and 2017 by conducting our own analysis of 53 businesses.

The survey included the size of the enterprise, the existence of access to the given activity and management, the characteristics of the financial structure, the quality of relationships between suppliers and customers, the evaluation of the liquidity structure, and one of the question-groups dealt with the controlling parameters of the ventures: with planning-analysis, directing and information procedures, furthermore with expense calculation and allocation, which is still the weakest point of the SMEs' management. Another new point of inquiry is the study of the supplier-customer relations which is important for risk reduction and which can be considered independently of management (the customers' willingness to pay, the fairness of the suppliers in the case of deadlines and fulfilment)

Regarding the judicial distribution of SMEs, three categories were distinguished: individual holdings, limited partnerships (LP) and limited liability companies (LC) appear ( $2^{\text {nd }}$ figure).

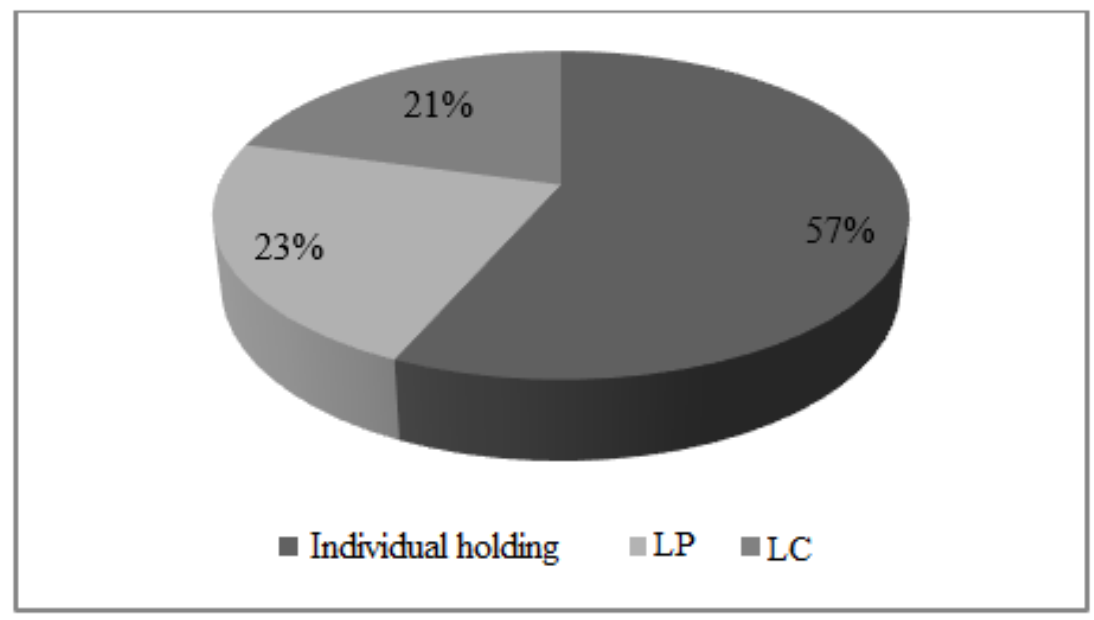

Figure 2: The judicial distribution of the studied enterprises, \% 
Several individual holdings with great capitalisation were in the circle of examination in 2016, these businesses pay attention to the activity, the additional processes (e. g. marketing, planning etc.) and ensure serious energy resources to increase the standards of the activity and to decrease the negative effects of the risks.

In order for the activity to be successful, professionalism and the mastery of business and management are essential. In the case of $90 \%$ of the enterprises, professional competence was documented, the directors had a specialised qualification by the time of launching the enterprise, or they acquired the necessary certificates in the very beginning. Professional competence is also shown by the fact that $57 \%$ of the managers possess higher education degrees.

In risk reduction, the management's economic knowledge is still of outstanding importance. The $3^{\text {rd }}$ figure shows the appearance of this kind of knowledge according to enterprise forms.

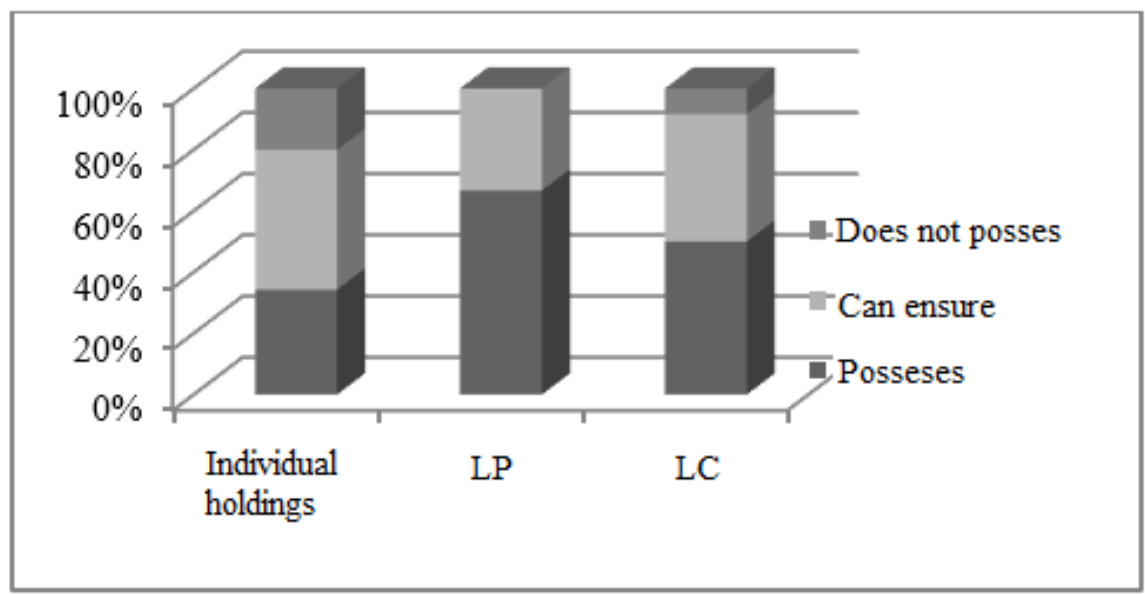

Figure 3: The entrepreneur's economic knowledge.\%

According to the views of enterprises, the quality of supplier-consumer relations is decisive. It is natural that the businesses created a stable supplier-consumer environment trying to achieve reliability for years, but the expectations of improvement urge the enterprises to grow and widen the circle of their former partners. These new relations carry the appearance of risks, but these risks are taken on by the directors and a great percentage of them try to manage these risks by using different procedures to grade the consumers and the suppliers. In the survey, the competition of suppliers and consumers could not be comprehensively examined, since most of the individual holdings do not apply this. Companies - where management possesses knowledge of business conducts - choose and change their suppliers and classify their consumers deliberately according to the contribution to the revenue and to the cover.

The $4^{\text {th }}$ figure demonstrates the methods for choosing suppliers, the $5^{\text {th }}$ shows the methods for ratifying consumers in the case of different enterprise forms. 


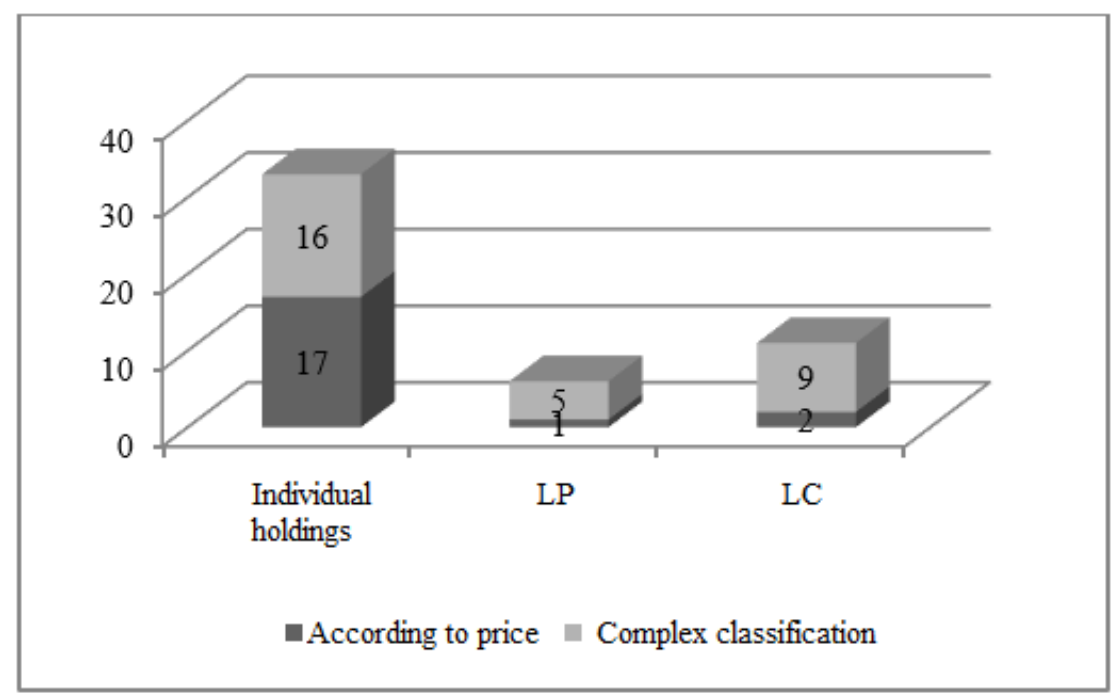

Figure 4: The classification of the enterprises' suppliers, pcs

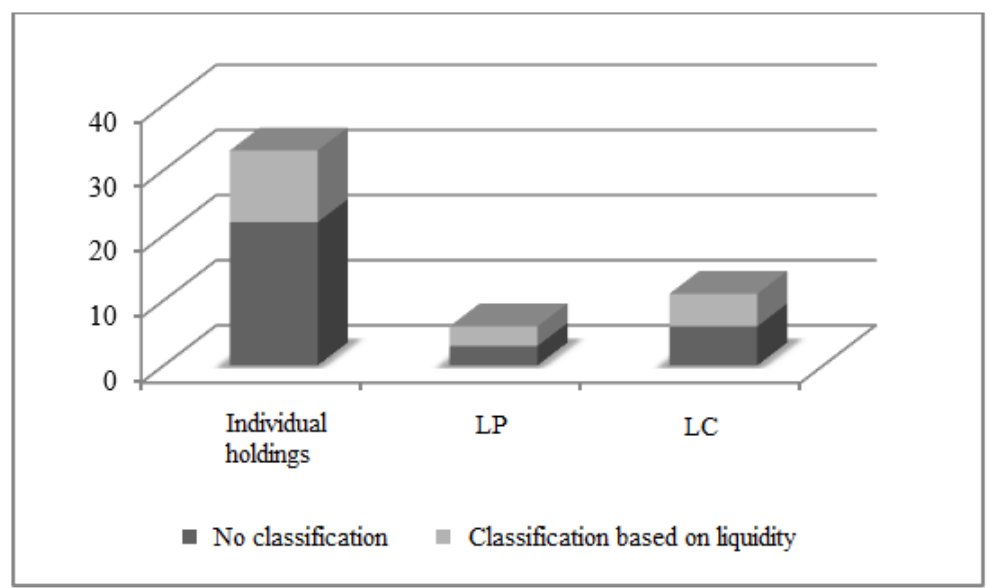

Figure 5: The classification of the enterprises' consumers, pcs

It is not surprising that the enterprises put a greater emphasis on choosing and classifying the suppliers, even if they maintain a special activity. Mostly, the circle of subcontractors is given in a specific geographical region and changing it is not possible/ worthwhile. The enterprises see the continuity of the production-service firstly in the availability of the direct inputs and not in the stability of the consumer circle, even though the continuity of the revenues and the competent measurement of the cover are conditions of the stable and plannable functioning.

\section{Summary}

Overall, we can establish that the enterprises - regardless of their size - can handle the effects of risk factors throughout their management activity. This is more successful when they can use the available tools, such as planning, plan-fact analysis, the ranking of partners, communication, etc., which are in close relationship with controlling. This activity faces obstacles especially in the case of SMEs, where the indirect production of assets often takes a backseat, not considering its long-term advantages. 


\section{Acknowledgments}

This research is supported by EFOP-3.6.1-16-2016-00006 "The development and enhancement of the research potential at John von Neumann University" project. The Project is supported by the Hungarian Government and co-financed by the European Social Fund for Dr. Vilmos LAKATOS and supported by New National Excellence Program for Ms. IPOLYI Vanda Vivien and Ms. TÍMÁR Tímea.

\section{Bibliography}

[1] [1] “ KSH A kis- és középvállalkozások jellemzői - adat-eloállítás új módszertannal 2016. november 2-11p.

[2] Békés G.- Muraközy B. (2012): Magyar gazellák. A gyors növekedésű vállalatok jellemzői és kialakulásuk elemzése. Közgazdasági Szemle. 49(3): 233-262.

[3] Csikány - Takács: A gazellák húzzák a magyar gazdaságot? - avagy a gyorsan növekvő kkv-k jellemzői, hazai helyzetük Acta Carolus Robertus 5 (2) 2015. http://real.tak.hu/3123.3/ 2-8p. Letöltés: 2017.08.21.

[4] Bárczi - Szabó - Zéman: A kockázatkezelés controlling vetületei Controller Info II. évf. 2014.1. sz. http://controllerinfo.hu/a-kockazatkezeles-controlling-vetuletei

[5] Kadocsa Gy.:A hazai kis és közepes vállalkozások helyzete és fejlesztési lehetőségei http://kgk.uniobuda.hu/sites/default/files/o1 Kadocsa Gyorgy.pdf Letöltés 2017.08.22. 49-57 p. 